\title{
Precipitating factors of porphyria cutanea tarda in Brazil with emphasis on hemochromatosis gene (HFE) mutations. Study of 60 patients
}

\author{
Fatores precipitantes na porfiria cutânea tardia no Brasil com ênfase \\ nas mutações do gene (HFE) da hemocromatose. Estudo de 60 casos
}

\author{
Fatima Mendonça Jorge Vieira ${ }^{1}$ \\ Eduardo Luiz Rachid Cançado ${ }^{4}$
}

\author{
Maria Cristina Nakhle ${ }^{2}$ \\ Vitor Manoel Silva dos Reis ${ }^{5}$
}

Clarice Pires Abrantes-Lemos ${ }^{3}$

DOI: http://dx.doi.org/10.1590/abd1806-4841.20132048

\begin{abstract}
BACKGROUND: Porphyria cutanea tarda is the most common form of porphyria, characterized by the decreased activity of the uroporphyrinogen decarboxylase enzyme. Several reports associated HFE gene mutations of hereditary hemochromatosis with porphyria cutanea tarda worldwide, although up to date only one study has been conducted in Brazil.

OBBECTIVES: Investigation of porphyria cutanea tarda association with C282Y and H63D mutations in the HFE gene. Identification of precipitating factors (hepatitis C, HIV, alcoholism and estrogen) and their link with HFE mutations.

MEIHODS: An ambispective study of 60 patients with PCT was conducted during the period from 2003 to 2012. Serological tests for hepatitis $\mathrm{C}$ and HIV were performed and histories of alcohol abuse and estrogen intake were investigated. HFE mutations were identified with real-time PCR.

RESULTS: Porphyria cutanea tarda predominated in males and alcohol abuse was the main precipitating factor. Estrogen intake was the sole precipitating factor present in $25 \%$ of female patients. Hepatitis $\mathrm{C}$ was present in $41.7 \%$. All HIV-positive patients $(15.3 \%)$ had a history of alcohol abuse. Allele frequency for HFE mutations, i.e., $\mathrm{C} 282 \mathrm{Y}(\mathrm{p}=0.0001)$ and $\mathrm{H} 63 \mathrm{D}(\mathrm{p}=0.0004)$, were significantly higher in porphyria cutanea tarda patients, compared to control group. HFE mutations had no association with the other precipitating factors.

CoNcLusions: Alcohol abuse, hepatitis Cand estrogen intake are prevalent precipitating factors in our porphyria cutanea tarda population; however, hemochromatosis in itself can also contribute to the outbreak of porphyria cutanea tarda, which makes the research for HFE mutations necessary in these patients Keywords: Hemochromatosis; Hepatitis; Iron overload; Mutation; Porphyria cutanea tarda
\end{abstract}

Resumo: FuNDAMENTOS: A porfiria cutânea tardia é a forma mais comum das porfirias e caracteriza-se pela diminuição da atividade da enzima uroporfirinogênio descarboxilase. Há vários relatos da associação das mutações do gene HFE da hemocromatose hereditária com porfiria cutânea tardia no mundo, mas até hoje apenas um estudo foi realizado no Brasil.

OBBEIIVos: Estudar a associação da porfiria cutânea tardia com as mutações C282Y e H63D do gene HFE. Identificar os fatores precipitantes (hepatite C, HIV, etilismo e estrógeno) e sua relação com as mutações HFE.

MÉrodos: Estudo ambispectivo de 60 pacientes com porfiria cutânea tardia no período de 2003 a 2012. Investigou-se as sorologias para hepatite C, anti-HIV, histórico de etilismo e ingestão de estrógenos. As mutações HFE foram identificadas com PCR em tempo real.

RESULTADOS: A porfiria cutânea tardia predominou no sexo masculino e o etilismo foi o principal fator precipitante. A ingestão de estrógenos foi o único fator precipitante em $25 \%$ das mulheres. A hepatite C estava presente em 41,7\%. Todos os pacientes com HIV $(15,3 \%)$ apresentavam etilismo associado. A frequência dos alelos C282Y ( $\mathrm{p}=0,0001)$ e H63D ( $\mathrm{p}=0,0004)$ do gene HFE foi significativamente mais elevada nos pacientes com porfiria cutânea tardia em relação à população controle. As mutações HFE não apresentavam associação com os demais fatores precipitantes.

CoNCLusõEs: Etilismo, hepatite C e ingestão de estrógenos (em mulheres) são fatores precipitantes prevalentes na nossa população com porfiria cutânea tardia, entretanto a hemocromatose isoladamente também pode contribuir para o desencadeamento da porfiria cutânea tardia, o que torna a pesquisa das mutações HFE necessária nestes pacientes.

Palavras-chave: Hemocromatose; Hepatite; Mutação; Porfiria cutânea tardia; Sobrecarga de ferro

Received on 05.08.2012.

Approved by the Advisory Board and accepted for publication on 09.09.2012.

* Work performed at the Department of Dermatology of Medical School of São Paulo University and Department of Gastroenterology of Clinical Division (Hepatology Branch) of Medical School of São Paulo University - São Paulo (SP), Brazil.

Financial support: Fundação de Apoio à Pesquisa do Estado de São Paulo (Fapesp) - No do projeto: 2010/51781-4.

Conflict of interests: none.

MD. PhD and Master's Degree. Department of Dermatology, Medical School of São Paulo University (FMUSP) - Sao Paulo (SP), Brazil.

Biomedical Scientist. Master's Degree. Tropical Medicine Institute of São Paulo University (IMT-USP) - São Paulo (SP), Brazil.

Biomedical Scientist. Master's Degree. Tropical Medicine Institute of São Paulo University (IMT-USP) - São Paulo (SP), Brazil.

MD. PhD. Associate Professor. Department of Gastroenterology, Clinical Division, Hepatology Branch. Medical School of São Paulo University (FMUSP) - São Paulo (SP), Brazil.

5 MD. PhD and Full Professor. Department of Dermatology. Medical School of São Paulo University (FMUSP) - São Paulo (SP), Brazil. 


\section{INTRODUCTION}

Porphyria cutanea tarda (PCT) is the most common form of porphyria, characterized by decreased activity of uroporphyrinogen decarboxylase (UROD) enzyme and consequent accumulation of uroporphyrins and hepta-carboxyl porphyrinogens, predominantly in the liver. ${ }^{1}$ Clinically it is characterized by skin fragility, hyperpigmentation and blistering affecting photo exposed areas, facial hypertrichosis and laboratory exams indicating iron overload and increased levels of liver enzymes. ${ }^{2}$ Diagnosis is based upon clinical manifestations, dosage of 24-hour urinary porphyrins (URO/COPRO > 3:1) and increased fecal levels of isocoproporphyrins (ISOCOPRO) or increase in plasma porphyrins in anuric patients. ${ }^{2}$ PCT can be induced by several precipitating factors: alcoholism, estrogens, viral infections, conditions which lead to iron overload (hereditary hemochromatosis, hemodialysis, etc.) and exposure to polyhalogenated aromatic hydrocarbons triggering toxic PCT. Most patients present multiple precipitating factors. Individuals suffering from PCT are apparently genetically predisposed to developing UROD deficiency in response to liver damage. ${ }^{3}$ Iron acts as a switch that controls the generation of UROD inhibitors, commencing a vicious cycle of UROD inactivation; its removal allows restoration of UROD activity. ${ }^{4}$ Remission after phlebotomy and treatment failure when iron supplement is administered, suggests that iron has an important role in the pathogenesis of the disease. ${ }^{5,6}$ Interaction occurs between hereditary and acquired factors implied in UROD inactivation; however, these interactions remain undefined. ${ }^{7}$

As alcohol consumption is associated with iron overload, several studies encountered an association with HFE mutations. ${ }^{8}$ The pathogenic role of hepatitis $\mathrm{C}$ virus (HCV) in triggering PCT has been reported since 1992 and a meta-analysis of 50 studies was performed by Gisbert et al. ${ }^{9}$ The calculated average of $\mathrm{HCV}$ prevalence was $47 \%$ and varied depending on the country and type of PCT (57\% in sporadic PCT and $26 \%$ in familial PCT). ${ }^{9}$ Association of PCT with human immunodeficiency virus (HIV) infections has been suggested; however, most of these patients have other precipitating factors, such as alcoholism, iron overload and co-infection by $\mathrm{HCV}^{10}{ }^{10}$ Estrogen is an independent precipitating factor for the development of PCT; no hepatic siderosis was identified in these patients. ${ }^{11}$ There is a genetic predisposition to PCT in these patients, as $84 \%$ have decreased UROD activity, approximately $50 \%$ of normal value. ${ }^{3}$ PCT can occur in patients with chronic renal failure (CRF) undergoing hemodialysis, by preexisting decrease of hepatic UROD activity. ${ }^{12}$

In 1996, Feder et al. encountered two missense mutations, C282Y and H63D, in the HFE gene located on p21.3 region of chromosome $6 \mathrm{p}$, which accounts for most cases of hereditary hemochromatosis $(\mathrm{HH})$ "type I" (88\% of $178 \mathrm{HH}$ patients in the study). ${ }^{13}$ Several literature studies exist which describe increased frequency of HFE gene mutations in patients with PCT (Chart 1). On chart 1 we computed the frequencies of $\mathrm{C} 282 \mathrm{Y}$ and H63D alleles in PCT patients as well as control populations of different countries, calculating p-value. C282Y mutation originated in the population of Northwestern Europe (Celts, Vikings or Germans) and its worldwide distribution reflects migration of these populations, i.e., higher incidence occurs among Caucasians in Northwestern Europe, Canada, USA, Australia, New Zealand and South Africa. ${ }^{14}$ These mutations are rare among Asian populations, Pacific Islanders, indigenous Australians, Africans and South Americans. ${ }^{15}$ In Chile the frequency of HFE mutations in patients suffering from PCT was not different from the control group. ${ }^{16}$ In Germany and USA the frequency of C282Y and $\mathrm{H} 63 \mathrm{D}$ mutations is higher in patients suffering from PCT, compared to control population. ${ }^{11,17,18}$ However, in one of the studies conducted in Germany no difference was observed in the frequency of H63D mutation. ${ }^{18}$ France and Portugal presented a greater frequency of $\mathrm{C} 282 \mathrm{Y}$ mutation in the normal population in the North rather than in the South, probably due to the increased influence of Celtic origin in the North. ${ }^{19,20}$ The role of S65C mutation does not appear to be decisive in PCT, as studies demonstrate that prevalence was no different between patients suffering from PCT and the control group. ${ }^{20}$ In the United Kingdom, Australia and São Paulo, Brazil, the C282Y mutation frequency was higher in PCT patients compared to controls, and no difference was observed in H63D mutation. ${ }^{21,22,23}$ Association between H63D mutation and PCT has been described in studies in the Mediterranean region. France, Spain, Italy, and Brazil showed a high frequency of H63D mutation in their populations. ${ }^{20,23,24,25}$ In Spain there was a significant association of the two mutations only in sporadic PCT and not in the familial form..$^{25}$

The 'major' mutation is caused by a guanine to adenine transition at nucleotide 845 of the HFE gene (845G A), which leads to replacement of cysteine by tyrosine at amino acid position 282 in the HFE protein, currently called ' $\mathrm{C} 282 \mathrm{Y}^{\prime}$ mutation. The 'minor' mutation is a replacement of cytosine by guanine at nucleotide 187 of the HFE gene (187C G), resulting in replacement of histidine by aspartic acid in amino acid position 63 of HFE protein, named 'H63D' mutation. ${ }^{26}$

The C282Y mutation abolishes HFE protein interaction with transferrin receptor (TfR), which may be enough to cause an iron deposition overload. ${ }^{27}$ Now mutation H63D induces a functional change, 


\begin{tabular}{|c|c|c|c|c|c|c|c|c|}
\hline \multirow{3}{*}{$\begin{array}{l}\begin{array}{l}\text { STUDY } \\
\text { Author / Year }\end{array} \\
\text { Tannapfel, 20017 }\end{array}$} & \multirow{3}{*}{$\begin{array}{l}\text { Country } \\
\text { Germany }\end{array}$} & \multicolumn{3}{|c|}{$\begin{array}{l}\text { Allele frequency in } \\
\text { control population (\%) }\end{array}$} & \multicolumn{3}{|c|}{$\begin{array}{l}\text { Allele frequency } \\
\text { in PCT }(\%)\end{array}$} & \multirow[t]{2}{*}{ p-value* } \\
\hline & & $\mathrm{Nr}$. & $\mathrm{C} 282 \mathrm{Y}$ & H63D & Nr. & $\mathrm{C} 282 \mathrm{Y}$ & H63D & \\
\hline & & 115 & 1.3 & 5.2 & 190 & 30.3 & 27.9 & C282Y e H63D; $p<0.0001$ \\
\hline Frank, $2006^{18}$ & Germany & 54 & 3 & 19 & 51 & 16 & 22 & $\mathrm{C} 282 \mathrm{Y}, \mathrm{p}<0.0013 ; \mathrm{H} 63 \mathrm{D} \mathrm{p}=0.6083$ \\
\hline Brady, $2000^{21}$ & United Kingdom & 10566 & 8.2 & 15.3 & 84 & 36.9 & 14.9 & C282Y, $p<0.0001 ; \mathrm{H} 63 \mathrm{D}, \mathrm{p}=1.0000$ \\
\hline Stuart, $1998^{22}$ & Australia & $\begin{array}{l}\text { Outros } \\
\text { estudos }\end{array}$ & & & 27 & 27.8 & 25.9 & $\begin{array}{l}\mathrm{p}<0.001 \text { for } \mathrm{C} 282 \mathrm{Y} / \mathrm{C} 282 \mathrm{Y} \text { and } \mathrm{C} 282 \mathrm{Y} / \mathrm{H} 63 \mathrm{D} \\
\text { Used control population of other studies. }\end{array}$ \\
\hline Bulaj, $2000^{11}$ & USA & 56 & 6.2 & 10.7 & 87 & 30.5 & 17.8 & C282Y, $\mathrm{p}<0.0001 ; \mathrm{H} 63 \mathrm{D}, \mathrm{p}=0.1271$ \\
\hline Chiavérini, $2003^{20}$ & Southern France & 58 & 0.9 & 12.9 & 33 & 9 & 30.3 & $\mathrm{C} 282 \mathrm{Y}, \mathrm{p}=<0.0097 ; \mathrm{H} 63 \mathrm{D}, \mathrm{p}=0.0060$ \\
\hline Enriquez de & Spain & 50 & 2 & 18 & 69 PCTs & 10.8 & 32.6 & PCTs - C282Y $p=0.0095 ; \mathrm{H} 63 \mathrm{D} p=0.0119$ \\
\hline Salamanca, $1999^{25}$ & & & & & 19PCTf & 7.9 & 15.8 & PCTf - C282Y $p=0.1281 ;$ H63D $p=1.0000$ \\
\hline Sampietro, $1998^{24}$ & Northern Italy & 128 & 0.7 & 12.9 & 68 & 2.2 & 29.4 & $\mathrm{C} 282 \mathrm{Y}, \mathrm{p}=0.3464 ; \mathrm{H} 63 \mathrm{D}, \mathrm{p}=0.0001$ \\
\hline Martinelli, $2000^{23}$ & São Paulo (Brazil) & 278 & 4 & 31.1 & 23 & 10.8 & 21.7 & $\mathrm{C} 282 \mathrm{Y}, \mathrm{p}=0.02 ; \mathrm{H} 63 \mathrm{D}, \mathrm{p}=1.0000$ \\
\hline Wolff, $2006^{16}$ & Chile & $\begin{array}{l}178(\mathrm{H} 63 \mathrm{D}) \\
/ 82(\mathrm{C} 282 \mathrm{Y})\end{array}$ & 1.2 & 12.4 & 20 & 7.5 & 20 & $\mathrm{C} 282 \mathrm{Y}, \mathrm{p}=0.0527 ; \mathrm{H} 63 \mathrm{D}, \mathrm{p}=0.2128$ \\
\hline
\end{tabular}

Note: * Our calculation of p-value, considering allele frequency in each study; Nr. = Number of patients; PCTs = sporadic porphyria cutanea tarda; $\mathrm{PCTf}=$ familial porphyria cutanea tarda

which leads to a loss of ability to reduce affinity of TfR to transferrin. ${ }^{27}$ Regardless of the exact mechanism, adults with $\mathrm{HH}$ type 1 present a gradual increase in total body iron with increased transferrin saturation (Tsat) and serum ferritin, resulting in abnormal iron deposition, predominantly in hepatocytes but also affecting other organs. The more pronounced clinical manifestations are related to $\mathrm{C} 282 \mathrm{Y}$ mutation and milder ones are related to $\mathrm{H} 63 \mathrm{D}$ and $\mathrm{S} 65 \mathrm{C}$ mutations. ${ }^{14}$ Absence of mutations is named wild type (WT). C282Y/WT, H63D/WT and H63D/H63D genotypes are not associated with phenotypic manifestation of the disease, although they present a small elevation of iron saturation. ${ }^{28}$

Currently, the presence of homozygosis for C282Y, associated with evidence of iron overload, such as increase in concentration of hepatic iron, increase of transferrin saturation (Tsat) and ferritin levels are the gold standard for a definitive diagnosis of $\mathrm{HH} .{ }^{29}$ Gene expression (penetrance) is highly variable; not all homozygotes for C282Y will develop iron overload or $\mathrm{HH}$. It is estimated that $40.0 \%$ to $70.0 \%$ of homozygous individuals for C282Y will develop some laboratory evidence of iron overload without clinical complications and that at least $50.0 \%$ of males and $25.0 \%$ of females with this genotype will develop clinical complications, secondary to iron overload. ${ }^{30}$
One to $11.0 \%$ of compound heterozygotes will bring about clinical $\mathrm{HH} .{ }^{31}$ Apparently there are gene modifiers that regulate the manifestation of HFE mutations, which when combined with individual differences of iron loss (such as females who menstruate), result in a considerable variation in clinical manifestations of risk genotypes (C282Y/C282Y and C282Y/H63D). ${ }^{14}$ In H63D homozygotes, $80.0 \%$ are clinically normal and $20.0 \%$ will develop iron overload, which is almost twice the percentage found in individuals with WT/WT genotype; H63D mutation is associated with a milder form of $\mathrm{HH}^{32}$ The clinical symptoms of $\mathrm{HH}$ occur after the third decade of life, because iron deposition is gradual and cumulative. Iron build-up occurs in the liver (leading to cirrhosis and increased risk of hepatocellular carcinoma (HCC)), pancreas (diabetes mellitus), heart (heart failure and arrhythmia), osteoarticular system (arthralgia and osteoporosis) and pituitary gland (hypothyroidism, hypogonadism). Type II diabetes, joint pain and muscle fatigue are frequent manifestations. ${ }^{33}$

Most patients suffering from PCT present increased levels of serum iron and ferritin, so these changed parameters are not used to diagnose $\mathrm{HH}$ in these patients..$^{34,35}$ In addition, ferritin can be increased in alcoholics and in viral infections (HCV and HIV) associated with PCT. Several authors discovered larg- 
er parameters of iron levels in patients suffering from PCT, as well as C282Y homozygotes or C282Y / H63D compound heterozygotes. ${ }^{11}$ However, a German study with 190 cases of PCT demonstrated that there is no difference between serum iron, liver iron, transferrin saturation and liver enzymes in patients, with or without HFE gene mutations. ${ }^{17}$ Bulaj et al. did not observe a significant difference between the frequency of HCV in PCT patients with HFE mutations and those with wild type alleles (WT), suggesting that HFE mutations do not predispose them to HCV infection. ${ }^{11}$ Sampietro et al. in Northern Italy observed that there was an increase in the prevalence of H63D mutation, although this mutation was not linked to the iron status. ${ }^{24} \mathrm{As} \mathrm{HCV}$ is frequent in Italian patients suffering from PCT and rare in PCT patients of Northern Europe, Sampietro et al. examined a control group with active hepatitis $\mathrm{C}$ and without PCT, in order to discard a possible association between H63D mutation and HCV infection. Prevalence of HFE mutations in this group was identical to that observed in control groups, suggesting that the increased prevalence of H63D was in fact associated with PCT. ${ }^{24}$ The role of H63D mutation in hemochromatosis has not yet been clarified, as it is rare in classical hemochromatosis and frequent in normal individuals. Some authors suggest that H63D could be a polymorphic marker of another unknown HFE mutation. ${ }^{24}$

The aims of this study cover examination of PCT association with C282Y and H63D mutations of HFE gene in Brazilian patients and identification of associated precipitating factors (alcoholism, hepatitis C, HIV infection and ingestion of estrogens), as well as their relation with presence or absence of HFE mutations.

\section{MATERIALS E METHODS Patients}

Sixty patients were included in the study, during the period from 2003 to 2011. Ethnicities considered were: Euro-Brazilian, African Brazilian, Asian Brazilian and mixed ethnicities. The comorbidities were alcoholism, estrogen intake and virus infections (HCV and HIV). We included in the clinical history exposure to chlorinated hydrocarbons and similar clinical manifestations in the family. All patients signed a free and informed consent term approved by the Committee for Research Projects Analysis of the Hospital and had blood collected for research of hemochromatosis gene mutations (C282Y and H63D). The frequency of alleles of C282Y and H63D mutations in patients with PCT was compared with frequency of alleles obtained from another study carried out in the same hospital in São Paulo (HCFMUSP), with 395 blood donors, by Pereira et al. in 2001. ${ }^{36}$

\section{Method}

PCT diagnosis was based on clinical features and quantification of urinary porphyrins (by High Performance Liquid Chromatography - HPLC) in urine sample collected for 24 hours using URO:COPRO >3:1 ratio. Liver enzymes [alanine transaminase (ALT), aspartate transaminase (AST), gamma-glutamyl transpeptidase (GGT)] and iron profile (transferrin saturation (Tsat), serum iron, ferritin, and iron binding capacity) were requested. Biochemical iron overload and liver enzyme increase were taken into consideration when values recorded were above the upper limit of normal (ULN) levels in reference values established by the Central Laboratory Division routine.

The genomic DNA leukocyte was extracted by a modified Chomczynski and Sacchi method. ${ }^{37}$ The final quantification of DNA concentration was obtained by Nanodrop ${ }^{\mathrm{TM}}$ ND-1000 Spectrophotometer reading, by $260 \mathrm{~nm}$ ultraviolet light absorbance and degree of DNA purity, which was evaluated and determined by ratio of 260/A280 nm. DNA whose ratio was $\geq 1.8$ were used. DNA samples were stored in refrigerator at $2-8^{\circ} \mathrm{C}$ to be used in amplification reactions. $\mathrm{C} 282 \mathrm{Y}$ and $\mathrm{H} 63 \mathrm{D}$ mutation research was carried out by the real-time polymerase chain reaction (PCR-RT) technique, using 7300 Real Time PCR System ABI PRISM ${ }^{\mathrm{TM}}$ (APPLIED Ecosystem, USA). We used the detection system: Tammany ${ }^{\circledR}$ SNP Geno typing Assays (Applied Microsystems, USA), in which primers and probes labeled with fluorescent substances, in our case FAM ${ }^{\mathrm{TM}}$ and VIC ${ }^{\circledast}$, paired in the target DNA region, allowing the identification of different alleles.

The study had an perspective and not directional outline. Data were obtained in a longitudinal form. Measures were applied in order to analyze frequency of each genotype, as well as of C282Y and H63D alleles of HFE gene of hereditary hemochromatosis $(\mathrm{HH})$ in 60 patients with PCT, at 95\% confidence intervals, separating the following variables (precipitating factors): alcoholism, hepatitis $\mathrm{C}$ virus (HCV), human immunodeficiency virus (HIV), and estrogen intake. We verified if there was an association between mutations (C282Y and H63D) and the variables listed above using Fisher's Exact Test. The adopted significance level was $5 \%(p<0.05)$. We analyzed the relation of HFE genotype with iron profile (serum iron, ferritin, transferrin saturation) and liver enzymes (AST, ALT and GGT).

\section{RESULTS}

PCT predominated in males $(73.3 \%)$ and there was no difference regarding the age at which the disease began in males and females (average 44.7 years). 
The genotype did not interfere in age of onset of PCT. Mixed ethnicities were prevalent in most patients $(72 \%)$ and the other ethnic groups were: EuroBrazilian (23\%), African Brazilian (3\%) and Asian Brazilian (2\%). The precipitating factors considered were: alcoholism, hepatitis $\mathrm{C}$ virus $(\mathrm{HCV})$, estrogen intake, family history of PCT and diagnosis of hereditary hemochromatosis $(\mathrm{HH})$ (considering clinical manifestation and/or presence of C282Y/C282Y or C282Y/H63D mutations). The majority of patients (63\%) presented two or more coexisting precipitating factors. Graph 1 shows the distribution of number of precipitating factors coexisting in the population of 60 patients and these factors are described in table 1.

Chronic alcoholism was present in $71.7 \%$ (43 of 60 patients) and $48.8 \%$ (21 of 43 ) of these had HCV. Social alcoholism was referred by 10 of 60 patients (16.7\%). Anti-CV was positive in $41.7 \%$ (25 of 60 patients); $84 \%$ of these (21 of 25 ) were alcoholics and $20 \%$ (5 of 25) also presented positive anti-HIV. As for the HCV genotype, only nine patients were found to have it: two with genotype ' $1 a$ ', four with ' $1 b^{\prime}$ ' and three with ' $3 a$ '. Anti-HIV was positive in $15.3 \%$ (9 of 59 patients); all patients had chronic alcoholism and five of these also presented positive anti-CV.

Only PCT family history was investigated; it was not possible to determine dosage of UROD enzyme activity in erythrocytes or search for UROD mutations in these patients. PCT case histories in the family were present in $28.3 \%$ (17 of 60 patients). Among these cases: $17.6 \%$ ( 3 of 17 ) presented this factor as the main precipitating factor; $58.8 \%$ (10 of 17 ) were alcoholics, $17.6 \%$ (3 of 17 ) hereditary hemochromatosis and $23.5 \%$ (4 of 17) estrogen intake. All cases with a PCT family history were negative for hepatitis $C$.

Considering 16 women in this study separately, in $50 \%$ ( 8 of 16 ) PCT was triggered by estrogens, this

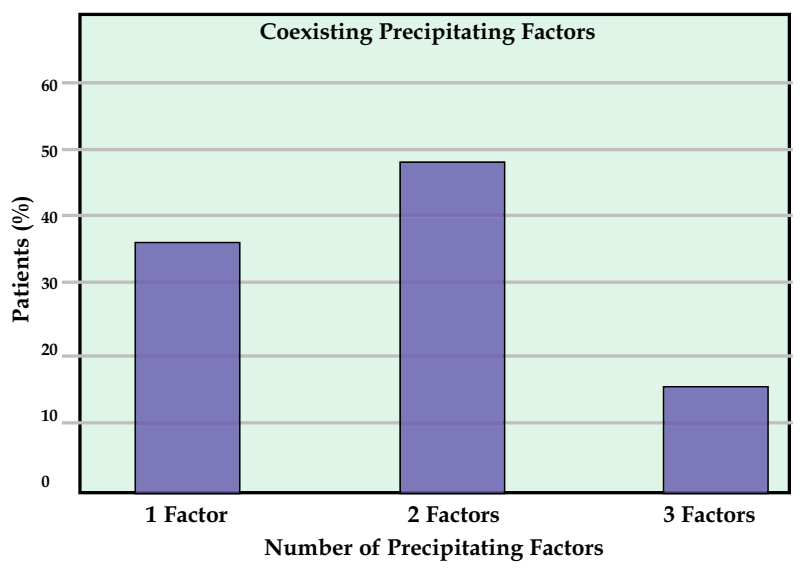

GRAPH 1: Distribution of coexisting precipitating factors being the main precipitating factor in four patients. As for the other four patients with PCT triggered by estrogen: one presented PCT family history, one had compound heterozygosity for HFE mutation (C282Y/H63D) and two had associated chronic alcoholism and family history. Still among females, in $25 \%$ (4 of 16) hepatitis $C$ was the precipitating factor, and three of these mentioned social alcoholism. One of the females presented a previous phenotypic diagnosis of $\mathrm{HH}$, which was the only precipitating factor in this patient. PCT family history was present in $31.25 \%$ (5 of 16 females), of these one featured family history as the only precipitating factor and another one featured only HFE mutation (C282Y/H63D genotype) without other precipitating factors. One female presented only social alcoholism.

The respective frequencies and confidence intervals for each precipitating factor or associated disease are described in table 2. Regarding associated diseases, two male patients were diagnosed with hepatocellular carcinoma (HCC). The first one was 60 years of age and developed HCC 32 years after onset

TABLE 1: Association of precipitating factors in 60 patients suffering from porphyria cutanea tarda

\begin{tabular}{lll}
\hline Precipitating Factors & $\mathbf{N}^{\mathbf{0}}$ Patients & $\%$ Patients \\
\hline Alcoholism + HCV & 16 & $26.7 \%$ \\
Alcoholism & 9 & $15.0 \%$ \\
Alcoholism + FH & 7 & $11.7 \%$ \\
Alcoholism + HCV + HIV & 5 & $8.3 \%$ \\
HCV & 4 & $6.7 \%$ \\
Estrogens & 4 & $6.7 \%$ \\
Alcoholism + HIV & 3 & $5.0 \%$ \\
Family history of PCT (FH) & 3 & $5.0 \%$ \\
FH + HH & 2 & $3.3 \%$ \\
Alcoholism + Estrogens + FH & 2 & $3.3 \%$ \\
Alcoholism + HIV + FH & 1 & $1.7 \%$ \\
Estrogens + FH & 1 & $1.7 \%$ \\
Estrogens + FH + HH & 1 & $1.7 \%$ \\
Hereditary Hemochromatosis (HH) & 1 & $1.7 \%$ \\
Social Alcoholism & 1 & $1.7 \%$ \\
\hline TOTAL & 60 & $100.0 \%$ \\
\hline
\end{tabular}

Note: $\mathrm{HCV}=$ Positive Serology for hepatitis $\mathrm{C}$ virus; $\mathrm{FH}=$ Family History of PCT; HIV = Positive Serology for HIV virus; $\mathrm{HH}=$ Hereditary Hemochromatosis (C282Y/C282Y or C282Y/H63D genotypes ou $\mathrm{HH}$ clinical phenotype). 
TABLE 2: Frequency of each precipitating factor or associated disease and its confidence interval

\begin{tabular}{lcccc}
\hline $\begin{array}{l}\text { Precipitating factor } \\
\text { or associated disease }\end{array}$ & Nr. & Estimate & \multicolumn{3}{c}{ CI (95\%) } \\
\cline { 5 - 6 } Alcoholism & 43 & $71.70 \%$ & $58.60 \%$ & $82,50 \%$ \\
Hepatitis C - HCV & 25 & $41.70 \%$ & $29.10 \%$ & $55,10 \%$ \\
Family history & 17 & $28.33 \%$ & $17.45 \%$ & $41,44 \%$ \\
HIV & 9 & $15.30 \%$ & $7.20 \%$ & $27,00 \%$ \\
Diabetes mellitus & 9 & $15.00 \%$ & $7.10 \%$ & $26,60 \%$ \\
Estrogen (only P) & 8 & $50.00 \%$ & $24.70 \%$ & $75,30 \%$ \\
Hereditary Hemochromatosis & 4 & $6.67 \%$ & $1.85 \%$ & $16,20 \%$ \\
Hepatocellular Carcinoma & 2 & $3.33 \%$ & $0.41 \%$ & $11,53 \%$ \\
\hline
\end{tabular}

Note: $९$ : female; CI: Confidence interval; 1 Group is composed of 16 female patients; 2 Patients possessing clinical manifestation of hereditary hemochromatosis or HFE gene mutation (C282Y/C282Y or H63D/C282Y genotype).

of disease; he presented several relapses as a consequence of not stopping alcohol consumption, and alcoholism and HCV were the precipitating factors. The second patient was diagnosed with HCC at 56 years of age, 15 years after onset of disease and presented the same precipitating factors as the previously described patient. Diabetes mellitus was present in $15 \%$ (9 of 60 patients) and one of the patients had prior clinical diagnosis of hemochromatosis. The other three patients with hemochromatosis genotype (one C282Y/C282Y and two C282Y/H63D) did not present diabetes.

Research of C282Y and H63D mutations in HFE gene for $\mathrm{HH}$ was carried out on 60 patients. The most frequent genotype was the wild type (WT/WT), found in 25 patients $(41.7 \%)$. The frequency of each genotype is described in table 3.

In our study, frequency of the C282Y allele was $8.3 \%$ and frequency of the H63D allele was $27.5 \%$. In order to compare these findings with a control group, a study was conducted with 395 normal people who were recruited from the Blood Bank of the same Hospital (HCFMUSP), to obtain allele frequency in controls (Table 3). Allele frequency was significantly higher in PCT patients in relation to the control group for C282Y (8.3\% vs. $1.77 \%$; odds ratio 5.02; IC [95\%] = $[4.1 \% ; 14.8 \%], p=0.0001], p=0.0001)$ and H63D $(27.5 \%$ vs. $14.05 \%$; odds ratio 2.32 ; IC $[95 \%]=[19.7 \%$; $36.4 \%], \mathrm{p}=0.0004)$.

Phenotypic or clinical manifestation of hemochromatosis was the only precipitating factor in the patient, who presented prior clinical diagnosis of $\mathrm{HH}$ despite heterozygous genotype for H63D. Two
TABLE 3: Frequency of each genotype and of C282Y and H63D alleles in 60 patients suffering from porphyria cutanea tarda and in 395 individuals of control population

\begin{tabular}{lll}
\hline Mutations & Nr. of Patients & \% Patients \\
\hline Genotype & & \\
C282Y / WT & 6 & 10 \\
C282Y / C282Y & 1 & 1.7 \\
H63D / WT & 21 & 35 \\
H63D / H63D & 5 & 8.3 \\
C282Y / H63D & 2 & 3.3 \\
WT / WT & 25 & 41.7 \\
\hline Total of patients & 60 & 100 \\
\hline Alleles in PCT & & \\
C282Y & $10 / 120$ alleles & 8.3 \\
H63D & $33 / 120$ alleles & 27.5 \\
Alleles in Control Population & & \\
C282Y & $14 / 790$ alleles & $1.77 \%$ \\
H63D & $111 / 790$ alleles & $14.05 \%$ \\
\hline
\end{tabular}

Note: $\mathrm{WT}=$ Wild Type

brothers had HH diagnosis only after research of HFE mutations (a C282Y/C282Y male and a C282Y/H63D female). Another compound heterozygous patient (C282Y/H63D) is being monitored, in order to observe if clinical signs of hemochromatosis are present.

Precipitating factors were related to serology for hepatitis $\mathrm{C}$ and there was no association with alcoholism, estrogens, HIV, HFE mutations or HH (Table $4)$. The only association $(p<0.05)$ that occurred was that none of the cases had a family history within the $\mathrm{HCV}$ group.

As we analyzed if precipitating factors (HCV, $\mathrm{HIV}$, alcoholism and estrogen) were associated with presence of alleles, no association was observed with C282Y or H63D alleles (Table 5). Patients with diabetes mellitus tended to have a higher frequency of H63D allele than patients without diabetes $(44.4 \%$ vs. $23.5 \%$; $\mathrm{p}$-value $=0.0834 ;$ as for $\mathrm{C} 282 \mathrm{Y}$ allele no such difference occurred. Patients with PCT family history had a tendency to an increased frequency of C282Y and H63D alleles, but it was not statistically significant ( $p=0.1440$ for C282Y; $p=0.2514$ for H63D).

In table 6, as biochemical parameters of patients with and without $\mathrm{HCV}$ were compared, it was observed: 1. Iron levels were lower in HCV patients, but this was not statistically significant; 2 . Liver enzymes were higher in HCV patients $(p<0.05)$.

Biochemical parameters were also distributed according to genotype in table 7 . It was observed that 
TABLE 4: Precipitating factors related to positive or negative serology for hepatitis $\mathrm{C}(\mathrm{HCV})$

\begin{tabular}{|c|c|c|c|c|c|}
\hline $\begin{array}{l}\text { Precipitating } \\
\text { Factors }\end{array}$ & $\begin{array}{c}\text { Nr. } \\
\text { Patients } \\
\text { tested }\end{array}$ & $\begin{array}{c}\text { Patients } \\
\text { with the } \\
\text { precipitating } \\
\text { factor }\end{array}$ & $\begin{array}{c}\text { Patients } \\
\text { with HCV } \\
\text { Nr. }=25\end{array}$ & $\begin{array}{c}\text { Patients } \\
\text { negative for } \\
\text { HCV } \\
\text { Nr. }=35\end{array}$ & p-value \\
\hline
\end{tabular}

$\begin{array}{llllll}\text { Alcoholism } & 60 & 43(71.7 \%) & 21(84.00 \%) & 22(62.85 \%) & 0.0886 \\ \text { Estrogen } 9 & 16 & 8(50 \%) & 0(0 \%) & 8(66.67 \%) & 0.0769 \\ \text { Hepatitis C-HCV } & 60 & 25(41.70 \%) & & & -- \\ \text { HIV } & 59 & 9(15.25 \%) & 5(20.83 \%) & 4(11.43 \%) & 0.464 \\ \text { FH } & 60 & 17(28.3 \%) & 0(0 \%) & 17(48.57 \%) & <0.0001 \\ \text { Risk for } \mathrm{HH}^{1} & 60 & 4(6.67 \%) & 0(0 \%) & 4(11.42 \%) & 0.1333 \\ \text { HFE Mutations }^{2} & 60 & 35(58.3 \%) & 13(52 \%) & 22(62.85 \%) & 0.4365 \\ \text { C282Y }^{3,4} & 60 & 9(15 \%) & 3(12 \%) & 6(17.14 \%) & 0.7222 \\ \text { H63D }^{3.4} & 60 & 28(46.7 \%) & 10(40 \%) & 18(51.42 \%) & 0.4386\end{array}$

Note: Nr.: number of tested patients;

\$: female;

HCV: hepatitis C virus;

HIV: human immunodeficiency virus;

FH: PCT family history;

HH: hereditary hemochromatosis.

${ }^{1}$ Phenotypic manifestation of patients with hemochromatosis $(\mathrm{HH})$ or genotype with greater risk of $\mathrm{HH}(\mathrm{C} 282 \mathrm{Y} / \mathrm{H} 63 \mathrm{D}$ and C282Y/C282Y;

${ }^{2}$ Total number of patients with at least one of alleles (C282Y and H63D);

${ }^{3}$ Present at least one C282Y and H63D mutation allele;

${ }^{4}$ Compound heterozygotes entering C282Y and H63D patients.
TABLE 5: Association of precipitating factors and associated diseases with presence of

C282Y and H63D alleles

\begin{tabular}{llllll}
\hline $\begin{array}{l}\text { Precipitating } \\
\text { factors / } \\
\text { associated } \\
\text { disease }\end{array}$ & & $\begin{array}{c}\text { \% with } \\
\text { allele } \\
\text { C282Y }\end{array}$ & p-value & $\begin{array}{c}\text { \% with } \\
\text { allele }\end{array}$ & p-value \\
\hline HCV & With & $6.0 \%$ & 0.5189 & $22.0 \%$ & 0.4042 \\
& Without & $10.0 \%$ & & $30.0 \%$ & \\
HIV & With & $5.5 \%$ & $>0.9999$ & $11.1 \%$ & 0.1487 \\
& Without & $8.8 \%$ & & $30.0 \%$ & \\
Alcoholism & With & $6.9 \%$ & 0.4665 & $22.1 \%$ & 0.1074 \\
& Without & $11.8 \%$ & & $38.2 \%$ & \\
Estrogen & With & $6.3 \%$ & $>0.9999$ & $43.8 \%$ & $>0.9999$ \\
& Without & $6.3 \%$ & & $43.8 \%$ & \\
Diabetes & With & $5.6 \%$ & $>0.9999$ & $44.4 \%$ & 0.0834 \\
& Without & $8.8 \%$ & & $23.5 \%$ & \\
FH & With & $14.7 \%$ & 0.1440 & $35.3 \%$ & 0.2514 \\
& Without & $5,8 \%$ & & $23,3 \%$ & \\
\hline
\end{tabular}

TABLE 6: Comparison between biochemical parameters (iron profile and liver enzymes) of patients with and without hepatitis $\mathrm{C}(\mathrm{HCV})$ associated to porphyria cutanea tarda

\begin{tabular}{lccccc}
\hline Parameters & Nr. & $\begin{array}{c}\text { With } \\
\text { HCV }\end{array}$ & Nr. & $\begin{array}{c}\text { Without } \\
\text { HCV }\end{array}$ & p-value \\
\hline Serum Iron x UNL & 18 & $0.93 \pm 0.33$ & 30 & $1.02 \pm 0.32$ & 0.463 \\
Ferritin x UNL & 18 & $1.94 \pm 1.33$ & 29 & $2.11 \pm 1.33$ & 0.702 \\
Transferrin & 17 & $46.28 \pm 17.28$ & 28 & $54.77 \pm 17.71$ & 0.058 \\
saturation (Tsat) \% & & & & & \\
Serum AST x UNL & 20 & $2.57 \pm 1.43$ & 32 & $1.73 \pm 0.82$ & 0.034 \\
Serum ALT x UNL & 20 & $2.52 \pm 1.46$ & 32 & $1.81 \pm 1.03$ & 0.032 \\
Serum GGT x UNL & 20 & $4.12 \pm 2.14$ & 32 & $2.91 \pm 2.91$ & 0.015 \\
\hline
\end{tabular}

Note: Nr. $=$ Number of patients; UNL $=$ Upper normal limit; ALT: Alanine transaminase; AST: aspartate transaminase and GGT: gammaglutamyl transpeptidase.

TABLE 7: Iron profile (serum iron, ferritin, transferrin saturation) and liver enzymes (AST, ALT and GGT) according to HFE genotype of patient (mean \pm standard deviation) in 60 patients

\begin{tabular}{|c|c|c|c|c|c|c|c|c|c|c|c|c|c|c|}
\hline Gen & $\mathbf{N}$ & $\%$ & $\mathrm{Nr}$ & $\begin{array}{l}\text { Serum Iron } \\
x \text { UNL }\end{array}$ & $\mathrm{Nr}$ & $\begin{array}{l}\text { Ferritin } \\
\mathrm{x} \text { UNL }\end{array}$ & $\mathrm{Nr}$ & Tsat (\%) & $\mathrm{Nr}$ & $\begin{array}{l}\text { Serum AST } \\
x \text { UNL }\end{array}$ & $\mathrm{Nr}$ & $\begin{array}{l}\text { Serum ALT } \\
x \text { UNL }\end{array}$ & $\mathrm{Nr}$ & $\begin{array}{l}\text { Serum GGT } \\
x \text { UNL }\end{array}$ \\
\hline $282 \mathrm{Y} / \mathrm{WT}$ & 6 & 10 & ( & $93 \pm 0.38$ & 6 & $2.25 \pm 0.95$ & 6 & $52.68 \pm 19.41$ & 6 & $2.61 \pm 1.49$ & 6 & $2.84 \pm 1.30$ & 0 & $4.55 \pm 3.41$ \\
\hline C282Y/C282Y & 1 & 1.7 & 1 & 1.13 & 1 & 1.45 & 1 & 89 & 1 & 0.44 & 1 & 0.45 & 1 & 0.86 \\
\hline $\mathrm{H} 63 \mathrm{D} / \mathrm{WT}$ & 21 & 35 & 17 & $1.05 \pm 0.39$ & 17 & $1.94 \pm 1.26$ & 16 & $51.48 \pm 20.24$ & 20 & $2.15 \pm 1.24$ & 20 & $2.13 \pm 1.21$ & 19 & $4.05 \pm 3.18$ \\
\hline H63D/H63D & 5 & 8.3 & 5 & $1.12 \pm 0.09$ & 5 & $2.15 \pm 1.21$ & 5 & $63.14 \pm 19.32$ & 5 & $1.93 \pm 0.98$ & 5 & $1.61 \pm 0.94$ & 5 & $2.06 \pm 0.56$ \\
\hline C282Y/H63D & 2 & 3.3 & 2 & $1.25 \pm 0.01$ & 2 & $3.17 \pm 1.53$ & 2 & $70.61 \pm 10.76$ & 2 & $1.65 \pm 0.83$ & 2 & $2.79 \pm 1.98$ & 2 & $2.29 \pm 2.8$ \\
\hline WT/WT & 25 & 41,7 & 23 & $0.89 \pm 0.25$ & 23 & $2.10 \pm 1.62$ & 22 & $46.53 \pm 13.28$ & 25 & $1.93 \pm 0.96$ & 25 & $1.96 \pm 1.12$ & 25 & $3.60 \pm 2.81$ \\
\hline
\end{tabular}

Note: Nr. = Number of tested patients; \% of patients; UNL: upper normal limit; Tsat $=$ transferrin saturation; UNL serum iron: $158 \mu \mathrm{g} / \mathrm{dL}$ (male) and $145 \mu \mathrm{g} / \mathrm{dL}$ (female); UNL ferritin: $400 \mathrm{ng} / \mathrm{dL}$ (male) and 150 $\mathrm{gg} / \mathrm{dL}$ (female); normal Tsat $=20 \mathrm{a}$ 40\%. Due to UNL differences between males and females, we have described how many times the value was above UNL 
serum iron and ferritin levels were higher in patients who were compound heterozygotes (C282Y/H63D) in relation to other genotypes. Transferrin saturation was higher in patients homozygous for C282Y (Tsat = $89 \%)$, followed by compound heterozygous (Tsat $=70.61 \pm 10.76 \%$ ) and homozygous for H63D $(63.14 \pm 19.32 \%)$. No difference was noted between genotypes in relation to liver enzymes.

\section{DISCUSSION}

Apparently an unexplained interaction between genetic and environmental factors is necessary for the PCT phenotypic expression in most cases. ${ }^{11}$ Most PCT patients presented multiple precipitating factors, of which the most common combination is between alcohol and $\mathrm{HCV}$ in $80 \%$ of males; in females, $40 \%$ have current estrogen intake as an isolated precipitating factor. ${ }^{11}$ In this study, the majority (63\%) presented two or more coexisting precipitating factors. Chronic alcoholism was the most frequent $(71.7 \%)$ precipitating factor. Alcoholism is a long-recognized important precipitating factor in PCT; it acts in synergy with other factors in predisposed individuals. ${ }^{38}$ Some authors suggest that chronic alcoholism may be associated with inheritance of HFE mutations, since C282Y mutation is dominant in countries where alcohol consumption is the most common PCT precipitating factor. ${ }^{35}$ However, in our study, no association existed between alcoholism and presence of any of the alleles; there is a greater proportion of patients with C282Y and H63D alleles among non-drinkers, but this difference did not have statistical significance.

In literature, anti-HCV antibody prevalence ranges from 8 to $91 \%$ and is related to the endemicity of $\mathrm{HCV}$ in the population. ${ }^{1,39}$ In this study, positive anti-HCV was $41.7 \%$ and the majority (84\%) presented association with alcoholism. Most of our patients $(60 \%)$ were diagnosed for HCV infection after the emergence of PCT, hence the need to investigate $\mathrm{HCV}$ in these patients. Chronic alcoholism places the patient at risk of developing PCT, regardless of presence or absence of HCV. It is suggested that increasing $\mathrm{HCV}$ prevalence can be related to increased alcohol consumption, due to the fact that positivity for antiHCV has been reported in up to $25 \%$ chronic drinker patients. ${ }^{40}$ However, our study has not demonstrated association of HCV with alcoholism. This study has also not observed a significant association of $\mathrm{HCV}$ with other precipitating factors (estrogen intake, HIV or presence of at least one HFE mutation allele). Evidently, certain individuals are predisposed to develop UROD deficiency, for the majority of individuals suffering from hepatitis $\mathrm{C}$ does not develop PCT. ${ }^{9}$ Liver enzymes were higher in the HCV group; however, serum iron and ferritin levels were lower in these patients. We would expect a greater increase of ferritin in patients with $\mathrm{HCV}$; probably what is interfering in this finding is the fact that in the group without $\mathrm{HCV}$, there are four HIV-positive patients and four patients with HFE mutations, which also contributed to increased ferritin levels.

Association with HIV occurred in nine patients (15.3\%); the diagnosis was prior to PCT in six cases and simultaneous in three cases; therefore, it is always recommended to investigate HIV in these patients. As has already been mentioned in literature, it cannot be concluded that HIV alone contributes to the onset of PCT, since all patients were associated with alcoholism and five also presented HCV. ${ }^{41}$

The increased incidence in females can be attributed to estrogen intake and increased consumption of alcohol by females in recent decades. Among the 16 females, estrogens have an important role in eight $(50 \%)$, and in $25 \%$ this was the only precipitating factor - similar to other studies, in which estrogen intake was the only triggering factor in more than 25\% of females with PCT. ${ }^{39}$ Three females had family history of PCT, which reinforces the idea that estrogen would act by inhibiting UROD, which genetically is already diminished. ${ }^{3}$

PCT family history was present in $25 \%$ of patients, but it was not possible to verify UROD erythrocyte activity or UROD gene mutations, preventing distinction between familial and sporadic PCT. This frequency is similar to that found in other studies, ranging from 20 to $29 \%$ in different populations of North America and Europe. ${ }^{4,39}$ Bulaj et al. reported that inherited deficiency of UROD does not change demographic and clinical features of PCT, i.e., if the same precipitating factors (excess iron, alcohol, $\mathrm{HCV}$ and estrogens) contributed to clinical expression of both types of PCT (familial or sporadic), for it is unlikely that this has affected our results. ${ }^{39}$

PCT is an iron-dependent disease in which iron overload is present in $60 \%$ to $70 \%$ of patients. ${ }^{34}$ In PCT, transferrin saturation and ferritin are similarly increased in patients with or without HFE mutations. ${ }^{22}$ As iron always has a changed profile in patients with PCT, a research of mutations is important to identify individuals at risk for developing iron overload. ${ }^{39}$

Brazilian population shows a high rate of ethnic miscegenation: the population is composed mainly of European descendants originating from Italy, Spain and Portugal, Afro-descendants (primarily from Angola, Congo and Mozambique) and native Indians; in addition, Brazil also received immigrants from Germany, Japan and the Middle East. ${ }^{42}$ There are several studies reporting C282Y and H62D allele frequencies in the normal Brazilian population..$^{36,42,43} \mathrm{C} 282 \mathrm{Y}$ mutation prevalence among healthy individuals 
(C282Y allele carrier frequency: 2.7 to $4.9 \%$ ) is lower than the observed among Europeans. In relation to H63D mutation, a high prevalence exists among healthy Brazilians (frequency of allele holders: $21.6 \%$ to $39.7 \%$ ); similar to that observed in White Europeans, particularly among Italians. In this study, a previous study by Pereira et al. , also held at this Hospital (HCFMUSP) with 395 blood donors in 2001, was used as control group. ${ }^{36}$ Variable frequencies of C282Y and H63D alleles between different ethnic groups occur in Brazil (Euro-Brazilians, Afro-descendants and a mixture of ethnicities); frequency was high among Euro-Brazilians, which supports the theory of European origin of mutations. ${ }^{36}$ As to total frequency of alleles in the normal population, we encountered $14 / 790=1.77 \%$ CI $[95 \%]=[0.97 \% ; 2.96 \%]$ for $\mathrm{C} 282 \mathrm{Y}$ and $111 / 790=14,05 \% \mathrm{CI}[95 \%]=[11.7 \%$; $16.67 \%$ ] for H63D. ${ }^{36}$ These results are very close to those found in Italian and Portuguese populations, which can be explained by the immigration observed in São Paulo. ${ }^{19,43,44}$

The prevalence of $\mathrm{HH}$ in Brazilian population is unknown. In Brazil, approximately one third of patients with $\mathrm{HH}$ classical phenotype do not present HFE mutations or other mutations associated with disease, suggesting that there may be other unknown mutations in the HFE gene or other genes involved in iron homeostasis. ${ }^{30}$ These findings also match reports from Italy, where approximately one third of patients with $\mathrm{HH}$ do no present $\mathrm{C} 282 \mathrm{Y}$ or H63D mutations. ${ }^{44}$ The difference in genotypes found in Brazil may be explained by Brazilian racial miscegenation, with predominant migration from Southern Europe, where mutations are less frequent, and a high influence of African descent and Native Americans, whose populations have a low frequency of these mutations. ${ }^{43}$ As in Brazilian population prevalence of S65C mutation is low in the healthy population and this mutation was not found among patients with iron overload, we do not consider research of these mutations relevant in patients of this study. ${ }^{30,43}$

Only one Brazilian study researched the association of HFE mutation (C282Y and H63D) in PCT. ${ }^{23}$ In 23 PCT patients, four patients presented C282Y mutation $(27.4 \%)$ and seven patients presented H63D mutation (30.4\%). The majority was heterozygous for the mutation; only one was homozygous for H63D mutation; one was compound heterozygous (C282Y/H63D) and none homozygous for C282Y. In the control group, 278 individuals were observed: C282Y mutation was found in $4 \%$ and H63D mutation in $31.1 \%$. Comparing both groups, there was a significant statistical difference between the two groups for C282Y mutation (OR=5.1, 95\% IC 1.5-17.6, $\mathrm{p}=0.02)$, but it was not the case for H63D (OR=1, 95\% IC 0.4-
2.4, $\mathrm{p}=1) \cdot{ }^{23}$ In our study, the frequency of two mutations was significantly higher in PCT patients in relation to control population for C282Y $(p=0.0001)$ and for H63D $(p=0.0004)$. We may conclude that HFE mutations increase the susceptibility of individuals to PCT; iron buildup precipitates manifestation of PCT in individuals already predisposed to the disease. The association of iron and chronic hepatitis $\mathrm{C}$ led to investigation of HFE mutations as a contributing factor for progression of liver disease, but the results are conflicting. Some researches report the association of HFE mutations with severe liver disease, while others have not found this association. ${ }^{8}$ The HCV infection and the C282Y mutation are independent precipitating factors, for in a study of Stuart et al. all HCV patients were homozygous for the wild type $\mathrm{e}^{22}$ and in a study of Toll et al. C282Y prevalence was higher among patients without $\mathrm{HCV}^{45}$ In our study, no association was observed between precipitating factors (HCV, HIV, alcoholism and estrogen) and presence of C282Y and H63D alleles. Patients with a PCT family history tended to have an increased frequency of C282Y and H53D alleles, but it was not statistically significant $(\mathrm{p}=0.1440$ and $\mathrm{p}=0.2514$, respectively); allele inheritance may contribute in part with PCT family history. There has been a tendency to an increase of $\mathrm{H} 63 \mathrm{D}$ allele among patients with diabetes mellitus $(p=0.0834)$, but not for C282Y alleles. This finding may be due to the fact of high prevalence of H63D mutation, present in the normal Brazilian population.

$\mathrm{HH}$ presents few specific signs or symptoms to alert the physician. The symptoms are nonspecific (e.g. arthralgia, weakness and fatigue) and do not help when there is suspicion of $\mathrm{HH} \cdot{ }^{46}$ Symptoms usually develop in patients over 40 years of age, at a time when iron deposition in organs may have caused irreversible damage in tissues, such as cirrhosis, hepatocellular carcinoma, arthritis, hypogonadism, diabetes mellitus and cardiomyopathy. ${ }^{47}$ One of the patients in this study had prior clinical diagnosis of $\mathrm{HH}$ as single precipitating factor of PCT. This patient was Oriental and heterozygous for H63D; probably other unknown mutations related to $\mathrm{HH}$ were contributing to the outbreak of PCT in this case. Neither the homozygous C282Y patient nor his compound heterozygous sister presented any other precipitating factors, except HFE mutations and family history. These three patients indicate that HFE mutations or clinical manifestation of hemochromatosis may contribute to the triggering of PCT, regardless of the presence of other precipitating factors.

The phenotypic expression of $\mathrm{HH}$ is higher in homozygous patients for $\mathrm{C} 282 \mathrm{Y}$ and in compound heterozygotes. ${ }^{11}$ Through discovery of the HFE gene, it 
was possible to identify 'potential' risk of developing iron overload, for not all C282Y homozygotes will develop iron overload or $\mathrm{HH}$, and it is not possible to predict the degree of phenotypic expression. In our study, it was observed that serum iron and ferritin levels were higher in compound heterozygous patients (C282Y/H63D) in comparison to other genotypes, and there was no difference in liver enzymes between genotypes. As for transferrin saturation, it was higher in homozygous $\mathrm{C} 282 \mathrm{Y}$ patients (Tsat $=89 \%$ ), followed by compound heterozygous (Tsat $=70.61 \pm 10.76 \%$ ) and H63D homozygotes (Tsat $=63.14 \%$ ), indicating that this parameter may be important when suspicion of association with HFE mutations arises regarding PCT patients. $\mathrm{HH}$ is suspected when transferrin saturation is $>50 \%$ in premenopausal females and $>60 \%$ in males or postmenopausal females but the elevation of Tsat is not specific to $\mathrm{HH} \cdot{ }^{48}$ Elevation of Tsat is the first manifestation of $\mathrm{HH}$ and may be high in young individuals, who still possess normal ferritin. ${ }^{49}$ In order to quantify iron overload in $\mathrm{HH}$, we usually use plasma ferritin, but this interpretation is distorted in PCT and in several other infectious and inflammatory diseases (acute phase reactant), e.g. in alcoholic hepatitis, nonalcoholic steatohepatitis, hepatitis C, rheumatoid arthritis and neoplastic diseases such as lymphoma. ${ }^{49}$ In patients with HFE mutations or clinical manifestation of $\mathrm{HH}$, which present factors that interfere with plasma ferritin, we usually suggest use of magnetic resonance imaging (MRI) of the liver in order to quantify liver iron concentration, a noninvasive method with a high degree of sensitivity and preciseness in order to measure iron concentration, as well as providing information about degree of fibrosis. ${ }^{50}$ One should always monitor iron levels in PCT patients (regardless of presence of HFE mutation), even when they are in a biochemical remission of disease, for these patients may present unknown factors that lead to an increase in iron level and subsequently lead to PCT recurrence.

\section{CONCLUSION}

Alcoholism, hepatitis C and estrogen intake (females) are precipitating factors, prevalent in PCT Brazilian population, but $\mathrm{HH}$ alone may also contribute to the onset of PCT, which makes research of HFE mutations or $\mathrm{HH}$ phenotypes in these patients important .

\section{ACKNOWLEGEMENTS}

This work was supported by grants from the Fundação de Amparo à Pesquisa do Estado de São Paulo (FAPESP). We are deeply thankful to Dr. João Renato Rebello Pinho and the Biologist Fernanda de Mello Malta, responsible for equipment 7300 Real Time PCR System ABI PRISM ${ }^{\mathrm{TM}}$ of Gastroenterology and Hepatology Laboratory of Institute of Tropical Medicine of Hospital das Clínicas (HCFMUSP); the Biologist Ana Lúcia Bernardes (for assistance in extracting genomic DNA from leukocytes), Lúcia Filomena Jorge for English language revision and João Italo Dias França for statistical analyses. 


\section{REFERENCES}

1. Teubner A, Richter M, Schuppan D, Köstler E, Stölzel U. Hepatitis C, hemochromatosis and porphyria cutanea tarda. Dtsch Med Wochenschr. 2006;131:691-5.

2. Vieira FMJ, Martins JEC. Porphyria cutanea tarda. An Bras Dermatol. 2006;81:573-84.

3. Sixel-Dietrich F, Doss M. Hereditary uroporphyrinogen-decarboxylase deficiency predisposing porphyria cutanea tarda (chronic hepatic porphyria) in females after oral contraceptive medication. Arch Dermatol Res. 1985;278:13-6.

4. Elder GH. Porphyria cutanea tarda. Semin Liver Dis. 1998;18:67-75.

5. Lundvall 0 . The effect of phlebotomy therapy in porphyria cutanea tarda. Its relations to the phlebotomy-induced reduction of iron stores. Acta Med Scand. 1971;189:33-49.

6. Lundvall 0 . The effect of replenishment of iron stores after phlebotomy in porphyria cutanea tarda. Acta Med Scand. 1971;189:51-63.

7. Phillips JD, Bergonia HA, Reilly CA, Franklin MR, Kushner JP. A porphomethene inhibitor of uroporphyrinogen decarboxylase causes porphyria cutanea tarda. Proc Natl Acad Sci U S A. 2007;104:5079-84.

8. Wallace DF, Subramaniam VN. Co-factors in liver disease: The role of HFE-related hereditary hemochromatosis and iron. Biochim Biophys Acta. 2009;1790:663-70.

9. Gisbert JP, Garcya-Buey L, Pajares JM, Moreno-Otero R. Prevalence of hepatitis C virus infection in porphyria cutanea tarda: systematic review and meta-analysis. J Hepatol. 2003;39:6207.

10. McAlister F, McCleon K, Hamilton PG, Houston S. Human immunodeficiency virus infection and porphyria cutanea tarda: coexistence of risk factors or causative association? Clin Infect Dis. 1995;20:348-51.

11. Bulaj ZJ, Phillips JD, Ajioka RS, Franklin MR, Griffen LM, Guinee DJ, et al. Hemochromatosis genes and other factors contributing to the pathogenesis of porphyria cutanea tarda. 18. Blood. 2000;95:1565-71.

12. Elder GH, Path MRC, Lee GB, Tovey JA. Decreased activity of hepatic uroporphyrinogen decarboxylase in sporadic porphyria cutanea tarda. N Engl J Med. 1978;299:274-8.

13. Feder JN, Gnirke A, Thomas W, Tsuchihashi Z, Ruddy DA, Basava A, et al. A novel MHC class I-like gene is mutated in patients with hereditary hemochromatosis. Nat Genet. 1996;13:399408.

14. Batts KP. Iron overload syndromes and the liver. Mod Pathol. 2007;20:S31-9.

15. Adams PC, Reboussin DM, Barton JC, McLaren CE, Eckfeldt JH, McLaren GD, et al. Hemochromatosis and Iron Overload Screening (HEIRS) Study Research Investigators. Hemochromatosis and iron-overload screening in a racially diverse population. N Engl J Med. 2005;352:1769-78.

16. Wolff CF, Armas RM, Frank J, Poblete PG. Mutations of hemochromatosis gene in volunteer blood donors and Chilean porphyria cutanea tarda patients. Medicina (B Aires). 2006;66:4216.

17. Tannapfel A, Stölzel U, Köstler E, Melz S, Richter M, Keim V, et al. C282Y and H63D mutation of the hemochromatosis gene in German porphyria cutanea tarda patients. Virchows Arch. 2001:439:1-5.

18. Frank J, Poblete-Gutiérrez $P$, Weiskirchen $R$, Gressner 0 , Merk HF, Lammert F. Hemochromatosis gene sequence deviations in German patients with porphyria cutanea tarda. Physiol Res. 2006;55:S75-83.

19. Cardoso CS, Oliveira P, Porto G, Oberkanins C, Mascarenhas M, Rodrigues P, et al Comparative study of the two more frequent HFE mutations (C282Y and H63D): significant different allelic frequencies between the North and South of Portugal. Eur J Hum Genet 2001;9:843-8.

20. Chiavérini C, Halimi G, Ouzan D, Halfon P, Ortonne JP, Lacour JP. Porphyria cutanea tarda, C282Y, H63D and S65C HFE gene mutations and hepatitis C infection: a study from southern France. Dermatology. 2003;206:212-6.

21. Brady JJ, Jackson HA, Roberts AG, Morgan RR, Whatley SD, Rowlands GL, et al. Co-inheritance of mutations in the uroporphyrinogen decarboxylase and hemochromatosis genes accelerates the onset of porphyria cutanea tarda. J Invest Dermatol. 2000;115:868-74.

22. Stuart KA, Busfield F, Jazwinska EC, Gibson P, Butterworth LA, Cooksley WG, et al. The C282Y mutation in the haemochromatosis gene (HFE) and hepatitis $C$ virus infection are independent cofactors for porphyria cutanea tarda in Australian patients. J Hepatol. 1998;28:404-9.

23. Martinelli AL, Zago MA, Roselino AM, Filho AB, Villanova MG, Secaf M, et al. Porphyria cutanea tarda in Brazilian patients: association with hemochromatosis C282Y mutation and hepatiits $C$ virus infection. Am J Gastroenterol. 2000;95:3516-21.

24. Sampietro M, Piperno A, Lupica L, Arosio C, Vergani A, Corbetta N, et al. High prevalence of the His63Asp HFE mutation in Italian patients with porphyria cutanea tarda. Hepatology. 1998;27:181-4

25. Enriquez de Salamanca R, Morales P, Castro MJ, Rojo R, González M, Arnaiz-Villena A. The most frequent HFE allele linked to porphyria cutanea tarda in Mediterraneans is His63Asp. Hepatology 1999:30:819-20.

26. Hanson EH, Imperatore G, Burke W. HFE gene and hereditary hemochromatosis: a HuGE review. Human Genome Epidemiology. Am J Epidemiol. 2001;154:193-206.

27. Feder JN, Penny DM, Irrinki A, Lee VK, Lebrón JA, Watson N, et al. The hemochromatosis gene product complexes with the transferrin receptor and lowers its affinity for ligand binding. Proc Natl Acad Sci U S A. 1998;95:1472-7.

28. Gochee PA, Powell LW, Cullen DJ, Du Sart D, Rossi E, Olynyk JK. A population based study of the biochemical and clinical expression of the H63D hemochromatosis mutation. Gastroenterology. 2002;122:646-51.

29. Bacon BR, Powell LW, Adams PC, Kresina TF, Hoofnagle JH. Molecular medicine and hemochromatosis: at the crossroads. Gastroenterology. 1999;116:193-207.

30. Cançado RD, Guglielmi ACO, Vergueiro CSV, Rolim EG, Figueiredo MS, Chiattone CS. Study of $\mathrm{C} 282 \mathrm{Y}, \mathrm{H63D}$ and S65C mutations in the HFE gene in Brazilian patients with iron overload. Rev Bras Hematol Hemoter. 2007;29:351-60.

31. Ferreira ACS, Oliveira VC, Caxito FA, Gomes KB, Castro AM, Pardini VC. Prevalence of C282Y and $\mathrm{H63D}$ mutations in the HFE gene of Brazilian individuals with clinical suspicion of hereditary hemochromatosis. Rev Bras Hematol Hemoter. 2008;30:379-83.

32. de Diego C, Opazo S, Murga MJ, Martínez-Castro P. H63D homozygotes with hyperferritinaemia: Is this genotype the primary cause of iron overload? Eur J Haematol. 2007;78:66-71.

33. Bonini-Domingos CR. Hereditary hemochromatosis and HFE gene mutations. Rev Bras Hematol Hemoter. 2006;28:239-45.

34. Fargion S, Fracanzani AL, Romano R, Cappellini MD, Faré M, Mattioli M, et al. Genetic hemochromatosis in Italian patients with porphyria cutanea tarda: possible explanation for iron overload. J Hepatol. 1996;24:564-9.

35. Sampietro M, Fiorelli G, Fargion S. Iron overload in porphyria cutanea tarda. Haematologica. 1999;84:248-53.

36. Pereira AC, Mota GF, Krieger JE. Hemochromatosis gene variants in three different ethnic populations: effects of admixture for screening programs. Hum Biol. 2001;73:145-51.

37. Chomczynski P, Sacchi N. Single-step method of RNA isolation by acid guanidinium thiocyanate-phenol-chloroform extraction. Anal Biochem. 1987;162:156-9.

38. Lundvall 0, Weinfeld A, Lundin P. Iron storage in porphyria cutanea tarda. Acta Med Scand. 1970;1-2:37-53.

39. Bulaj ZJ, Phillips JD, Ajioka RS, Franklin MR, Griffen LM, Guinee DJ, et al. Hemochromatosis genes and other factors contributing to the pathogenesis of porphyria cutanea tarda. Blood. 2000;95:1565-71.

40. Parés A, Barrera JM, Caballería J, Ercilla G, Bruguera M, Caballería L, et al. Hepatitis C virus antibodies in chronic alcoholic patients: association with severity of liver injury. Hepatology. 1990;12:1295-9.

41. Mansourati FF, Stone VE, Mayer KH. Porphyria cutanea tarda and HIV/AIDS: a review of pathogenesis, clinical manifestations and management. Int J STD AIDS. 1999;10:51-6.

42. Agostinho MF, Arruda VR, Basseres DS, Bordin S, Soares MC, Menezes RC, et al. Mutation analysis of the HFE gene in Brazilian populations. Blood Cells Mol Dis. 1999;25:324-7.

43. Bueno S, Duch CR, Figueiredo MS. Mutations in the HFE gene (C282Y, H63D, S65C) in a Brazilian population. Rev Bras Hematol Hemoter. 2006;28:293-5.

44. Piperno A, Sampietro M, Pietrangelo A, Arosio C, Lupica L, Montosi G, et al. Heterogeneity of hemochromatosis in Italy. Gastroenterology. 1998;114:996-1002.

45. Toll A, Celis R, Ozalla MD, Bruguera M, Herrero C, Ercilla MG. The prevalence of HFE C282Y gene mutation is increased in Spanish patients with porphyria cutanea tarda without hepatitis C virus infection. J Eur Acad Dermatol Venereol. 2006;20:1201-6.

46. McDonnell SM, Preston BL, Jewell SA, Barton JC, Edwards CQ, Adams PC, et al. A survey of 2,851 patients with hemochromatosis: symptoms and response to treatment. Am J Med. 1999:106:619-24.

47. Seamark CJ, Hutchinson M. Controversy in primary care: should asymptomatic haemochromatosis be treated? BMJ. 2000;320:1314-7.

48. Lyon E, Frank EL. Hereditary hemochromatosis since discovery of the HFE gene. Clin Chem. 2001:47:1147-56.

49. Bacon BR. Hemochromatosis: diagnosis and management. Gastroenterology. 2001;120:718-25.

50. Gandon Y, Olivié D, Guyader D, Aubé C, Oberti F, Sebille V, et al. Non-invasive assessment of hepatic iron stores by MRI. Lancet. 2004;363:357-62.

MAILING ADDRESS:
Fatima Mendonça Jorge Vieira
Rua Voluntários da Pátria, 4370, cj. 121 - Santana
02402-600 - São Paulo - SP
Brazil
E-mail: fmjvieira@hotmail.com

MAILING ADDRESS:

Rua Voluntários da Pátria, 4370, cj. 121 - Santana

02402-600 - São Paulo - SP

E-mail:fmjvieira@hotmail.com

How to cite this article: Vieira FMJ, Nakhle MC, Abrantes-Lemos CP, Cançado ELR, Reis VMS. Precipitating factors of porphyria cutanea tarda in Brazil with emphasis on hemochromatosis gene (HFE) mutations. Study of 60 patients. An Bras Dermatol. 2013;88(4):530-40. 